\title{
SOME ASPECTS REGARDING THE EUROPEAN SOCIAL DIALOGUE
}

\section{A. HURBEAN}

\author{
Ada Hurbean \\ Faculty of Law and Social Sciences \\ Department of Juridical and Administrative Sciences \\ University "1 Decembrie 1918” of Alba Iulia, Alba Iulia, Romania. \\ *Correspondence:M.M.TUDORASCU, Unirii St., No.15-17, Alba Iulia, Romania \\ E-mail: adahro@yahoo.com
}

\begin{abstract}
The concept of social dialogue is approached differently at international level. According to the definition proposed by the International Labour Organisation, the social dialogue represents the voluntary information, consultation and negotiation act issued in order to negotiate agreements between the social partners or to negotiate collective agreements. As a concept adopted at EU level, the social dialogue, established by the Treaty of Rome in 1957, is a process of continuous information and consultation between unions and employers, so as to reach understandings regarding the control of certain economic and social variables, both in macroeconomic and microeconomic level. No matter how this concept is understanding, the social dialogue is associated with the transition from a culture of conflict to a culture of partnership with consideration of the common interests of the social partners involved in a broader process of "social cooperation".
\end{abstract}

KEY WORDS: SOCIAL DIALOGUE, TRADE UNIONS, EMPLOYERS, SOCIAL PARTNERSHIP, COLLECTIVE AGREEMENTS.

\section{INTRODUCTION}

Worldwide, the social dialogue is considered a very useful tool in solving serious social problems, consequences of globalization. It is also used to establish how the resources are distributed, the costs and benefits of economic exchanges. In this respect, the state is interested to involve representative organizations of employers in making decisions, allowing them, in this way, to express opinions and to participate in the elaboration and implementation of economic measures, of general or particular order[1].

Thus, the first attempts at resolving some labour conflicts through negotiations between employers and employees are dating back to the nineteenth century. Only at the end of World War I, once with the establishment of the International Labour Organisation, we can talk about the birth of the principle of social dialogue (partnership) and of collective bargaining as techniques for solving specific problems of the employment relationships[2]..

The social partnership was regulated for the first time in Europe, especially by the Economic and Social Council which played an important role in covering in a climate of peace and understanding in society of periods of crisis in several countries, such as: France, Italy, Belgium and Holland. Subsequently, the present system has been adopted by some other countries, namely Australia, Japan, etc. 
When referring to social partnership, it is essential to focus the efforts of social partners in order to overcome the crisis and stabilize in the same time the socio-economic situation.

Internationally, about social dialogue and collective bargaining, it can be spoken only after World War I, more precisely, since 1919 when the International Labour Organisation was created (by the Peace Treaty of Versailles). However, the true consecration of collective bargaining was done by the Declaration of Philadelphia, adopted in 1944 as an addendum to the Constitution of the International Labour Organisation, in which it was also mentioned "effective recognition of the right of collective bargaining and cooperation of management and labour, in the continuous improvement of productive efficiency, and the collaboration of workers and employers in the preparation and application of social and economic policy". The requirement of social dialogue was synthesized in this important act in an imperative formulation: "the representatives of workers and employers, cooperating on an equal footing with those of governments, join with them in free discussions and democratic decision, with a view to the promotion of the common welfare".

Through the Convention no. 98/1949 on the implementation of the right to organise and to bargain collectively - ratified by Romania in 1958 - the General Conference of the International Labour Organisation has made an important step on the line of strengthening the social dialogue, aiming at "promoting and encouraging the full development and utilisation of machinery for voluntary negotiations of the collective agreement between the social partners with a view to the regulation of terms and conditions of employment by means of collective agreements".

The Council of Europe took the same position as the International Labour Organisation. In 1961, in Turin, the Council of Europe adopted the European Social Charter, providing a total of 31 guaranteeing fundamental rights, including the right to collective bargaining. In this respect, Article 6 of the Social Charter establishes the objectives of the social dialogue: joint consultation on matters of common interest, negotiation of the collective labour agreement, conciliation and voluntary arbitration for the settlement of any labour disputes.

The use of some procedures to ensure effective consultations between representatives of the Government, employers and workers has been the subject of numerous Articles of the Convention no. 144/1976 of the International Labour Organisation, regarding the tripartite consultations to promote the implementation of international labour provisions.

The jump from the recognition of the subjective right of social partners to organize and conduct negotiations to the awareness of the importance of negotiation, making it effective and operative, was conducted by the International Labour Organization through the adoption of Convention no. 154/1981 on promoting collective bargaining, adopted on 19 June 1981. This Convention was ratified by Romania by Law no. 112/1992, and certain goals were set in order to be respected, promoted and fulfilled. So, in art 5 of the mentioned law there is the idea that the collective negotiation must be available for the entire employee and all the employers from all branch of activities refereed and the collective negotiation must be progressively extended to all activities stipulated in convention. Also, it is necessary to encourage the development of the collective negotiation procedure rules between the employer and employee representatives, because the collective negotiation can be prevented by the invocation of lack of procedure rules or by the fact that these rules are insufficient or 
unclear. The last law objective is that the authorities and procedures that regulate the labour disputes must contribute to promote the collective negotiations.

The European Union adopted in December 1989 the Community Charter of the Fundamental Social Rights of Workers, which enshrines among the fundamental rights the right to information, consultation and negotiation, too.

By the Maastricht Treaty, targeting the social policy, it has been considerably strengthened the role of social partners at European level. The procedure of bargaining and consultation introduced by this treaty was drawn up by the Union of Industrial and Employers' Confederations of Europe (UNICE), the Organisation of Public Employers (CEEP) and by the European Trade Union Confederation (ETUC), during the social dialogue. It was subject to the Intergovernmental Conference approval in 1991. At the same time, by the Maastricht Treaty, the role of employers' organisations and of employees recognized as "social partners" received formalization at European level, for the first time in the history of European integration.

Specifically, the social dialogue is regulated at European level by Articles 151-156 of the Treaty on the Functioning of the European Union (TFEU). In accordance with Article 151 TFEU, the promotion of dialogue between management and labour is recognized as a common objective of the EU and Member States. The aim of the social dialogue is to improve the European governance by involving the social partners in the decisional and implementation process.

\section{BIPARTITE SOCIAL DIALOGUE}

Bipartite social dialogue, in particular, may be exercised at sectorial, inter-sectorial (or multi-industrial) and inter-professional level. The last situation is particularly important at European level where the issue regarding national diverging opinions (even within the same association) cannot be controlled. These three levels of application use different procedures and generate separate outlets. A sectorial agreement is almost always, in national experiences, a contractual agreement that defines the dynamics of wages, working hours, working conditions and other details compatible - as the rest of the understanding, too - with national laws. At European level there are still few cases of sectorial agreements that can be considered close to the national model of contractual agreements; there is no doubt regarding the fact that a contractual European area will be formed gradually. Nevertheless, since its inception, the bipartite social dialogue took the form of gathered opinions, statements and recommendations and the like, all instruments that are not accompanied by contractual obligations.

In 1992, the Social Dialogue Committee was created as the main forum for bipartite social dialogue at European level. Currently, the Social Dialogue Committee meets three or four times a year and is composed of 64 members (32 representing employers and 32 workers) either from European secretariats or from the national organizations. At the same time, the Single European Act created the legal basis for the development of a "social dialogue at the community level". In October 1991, UNICE, ETUC and CEEP adopted a joint agreement calling for mandatory consultation of the social partners in the preparation of legislation on social affairs and the possibility for social partners to negotiate framework agreements at Community level. The request was confirmed in the agreement annexed to the Maastricht Protocol on Social Policy, signed by all Member States except the United 
Kingdom. At national level, the social partners have benefited, thus, from the possibility to implement directives by a collective agreement.

Assimilation of the Agreement on Social Policy by the EC Treaty, following the entry into force of the Treaty of Amsterdam, has finally enabled the application of a single framework for social dialogue in the EU. The inter-professional results of the process were adoption of framework agreements on parental leave (1995), part-time work (1997) and fixed-term work (1999), implemented by Council directives.

At EU level, according to Article 154 TFEU, the Commission must consult the social partners before taking any action in the social policy field. The social partners may then choose to negotiate among themselves an agreement on the subject of the consultation and stop the Commission's initiative. The negotiation process can take up to nine months and the social partners have the following possibilities: they may conclude an agreement and jointly ask the Commission to propose that the Council adopt a decision on implementation, or having concluded an agreement between themselves, they may prefer to implement it in accordance with their own specific procedures and practices and those of the Member States ('voluntary' or, later on, 'autonomous' agreements), or they may be unable to reach an agreement, in which case the Commission will resume work on the proposal in question.

Negotiations between the social partners on a framework agreement on temporary agency work ended in failure in May 2001. Thus, in March 2002, the Commission adopted a proposal for a directive based on the consensus which had emerged among the social partners. After a modification of the proposal in November 2002, the process culminated in the adoption of Directive 2008/104. Similarly, after the social partners had expressed their unwillingness to engage in negotiations, in 2004 the Commission put forward a proposal on the revision of Directive 2003/88/EC concerning certain aspects of the organisation of working time, including recent developments such as on-call work and flexible weekly working time. Parliament, the Commission and the Council were subsequently unable to agree on the issue, and the European social partners tried to find an agreement during a yearlong negotiation process, which also broke down in December 2012 due to major differences on the treatment of on-call time as working time. It is therefore now up to the Commission to put forward a new proposal.

From 1998, following a Commission decision to establish specific bodies (Commission Decision 98/500/EC of 20 May 1998), sectoral social dialogue was also strongly developed. Several committees were created in the main economic fields and they produced valuable results. Sectoral social dialogue produced three European agreements on the organisation of working time for seafarers (1998), on the organisation of working time for mobile workers in civil aviation (2000) and on certain aspects of the working conditions of mobile workers assigned to interoperable cross-border services in the railway sector (2005).

These agreements were implemented by Council decision. The 'Agreement on workers' health protection through the good handling and use of crystalline silica and products containing it', signed in Aprilie 2006, was the first multi-sector outcome of the European social partners' negotiations. In 2014, the Council implemented, by means of a directive, a sectoral agreement concerning certain aspects of the organisation of working time in inland waterway transport from 2012.

In April 2012, the social partners in the hairdressing sector concluded an agreement on clear guidance for hairdressers to work in a healthy and safe environment throughout their 
careers, and requested a Council implementing decision. Since then, the matter has got no further than the Commission, which announced in its REFIT Communication of 18 June 2014 that it would not be submitting a proposal to the Council. This suggests that the Commission's role is evolving from that of an intermediary body to that of a player with its own tools, namely impact assessments to be conducted before deciding to turn a sectoral agreement into a directive, taking into account whether the Council is prone to agree on the directive, bearing in mind the principles of representativeness of social partners, subsidiarity and proportionality.

The agreement on teleworking concluded in May 2002 was implemented for the first time in accordance with the procedures and practices specific to the social partners and the Member States. 'Autonomous agreements' were also concluded by the social partners on work-related stress and on the European licence for drivers carrying out a cross-border interoperability service in 2004, as well as on harassment and violence at work (Aprilie 2007) and on inclusive labour markets (March 2010).

Following the changes introduced by the Treaty of Amsterdam, the consultation process has become even more important, since it covers all the fields now falling under Article 151 TFEU.

With the entry into force of the Lisbon Treaty, a new article (Article 152 TFEU) has been inserted, stating that 'the Union recognises and promotes the role of the social partners at its level, taking into account the diversity of national systems. It shall facilitate dialogue between the social partners, respecting their autonomy'. Article 53 TFEU also gives Member States the possibility to entrust the social partners with the implementation of a Council decision adopted on ratification of a collective agreement signed at European level.

However, since the economic and financial crisis started, social dialogue has increasingly suffered when crisis measures were implemented, being weakened by its decentralisation, a decline in bargaining coverage and state intervention in the area of wage policy. Against this background, and in view of the finding that the Member States in which the social partnership is strongest have been the most successful in overcoming the crisis, the new Commission undertook in November 2014 to re-launch and strengthen the dialogue with social partners, especially in the new economic governance set-up, as a prerequisite for the functioning of Europe's social market economy.

\section{TRIPARTITE SOCIAL DIALOGUE}

As regards the tripartite social dialogue, it should be noted that right from the beginning of the European integration process, it was felt as important that the economic and social actors should be involved in drafting the legislation. The Advisory Committee of the European Coal and Steel Community and the European Economic and Social Committee stand as testimony to this. Since the 1960s, there were a number of advisory committees whose role was to assist the Commission in formulating specific policies. In general, these committees, such as the Committee on Social Security for migrant workers, consist of representatives of national organizations of employers, of trade unions and representatives of the Member States. Since 1970, an important forum of tripartite social dialogue at European level was the Standing Committee on Employment, composed of 20 representatives of social partners, derived equally from trade unions and employers' organizations. Reformed in 1999, the Committee was fully integrated into the coordinated European strategy for employment. 
On the basis of joint contributions of the social partners at the summit in Laeken in December 2001, the Council launched a Tripartite Social Summit for Growth and Employment in March 2003 (Decision 2003/174 / EC of the Council), which replaced the Committee for employment. Its role is to facilitate continuous consultation between the Council, Commission and the social partners on economic, social and employment issues. Formalizing a process that develops since 1997, the summit currently includes the present Presidency of the EU Council and the two subsequent Presidencies, the Commission and the social partners. The three Council presidencies are normally represented by the Heads of State or Government and by the Ministers of Labour and Social Affairs. The representatives of the social partners are divided into two delegations of equal size, consisting of ten employees' representatives and ten employers' representatives, paying special attention to the need to ensure a balanced participation between men and women. Each group is composed of delegations of the European inter-professional organizations, representing either general interests or particular interests of supervisory and managerial staff and small and medium enterprises in Europe. Technical coordination is ensured by the ETUC for the employees' delegation and by UNICE for employers' delegation. Following the ratification of the Lisbon Treaty, the role of the Tripartite Social Summit for Growth and Employment Work is currently recognized in Article 152 TFEU.

\section{ROLE OF THE EUROPEAN PARLIAMENT REGARDING SOCIAL DIALOGUE}

Parliament has taken the view that social dialogue is an essential element in the traditions of the Member States and has called for a greater role for the 'trialogue' at European level. Its Committee on Employment and Social Affairs has extended frequent invitations to the social partners at EU level to present their views before a report or opinion on any relevant issues is delivered. It has also often reminded the Commission of the need for a coherent industrial policy at European level, in which the social partners should play a key role. The Lisbon Treaty has introduced a clear right for Parliament to be informed about the implementation of collective agreements concluded at Union level (Article 155 TFEU) and about the initiatives taken by the Commission to encourage cooperation between the Member States under Article 156 TFEU, including matters relating to the right of association and collective bargaining between employers and workers.

In the midst of the economic crisis, Parliament has reiterated the fact that social dialogue is vital in order to achieve the employment targets set out in the EU 2020 Strategy (2009/2220(INI)). In January 2012, it stressed that, in focusing on fiscal consolidation, the Annual Growth Survey's recommendations would hamper not only job creation and social welfare, but also social dialogue as such. Furthermore, in its resolutions on the 2014 European Semester cycle, Parliament once again stressed the importance of social dialogue and called for a reinforcement of the role of social partners in the new economic governance process. Regarding the economic adjustment programmes in the countries most affected by the crisis, Parliament, in its resolution of 13 March 2014 on employment and social aspects of the role and operations of the Troika (ECB, the Commission, IMF) with regard to euro area programme countries, stressed that the social partners at national level should have been consulted or involved in the initial design of programmes. [3] 
In European countries, the social dialogue was enacted in the years following the Second World War, especially under the shape of the Economic and Social Council, which played a special role in completing a social truce periods of the crisis in countries such as France, Italy, Belgium, Holland. If during the years 1960-1970 the forms of the Economic and Social Councils were felt in terms of economic developments in the context of social peace, after 1970, once with the oil crisis and the increasing unemployment phenomenon, the tripartite negotiations have experienced a setback, losing its effectiveness. Thus, it is explained the fact that bipartite negotiations at branch and enterprise level settled and consolidated on the right place of tripartism. One typical example is represented by Germany.

Although it was said that tripartism is specific to European countries, important national agreements on wages and incomes were achieved in Australia, and Japan holds consultations periodically in the Conference and Roundtable of Industrial and Labour Issues (Sanrokon).

Returning to Europe, it must be mentioned the crucial role that the Economic Council plays in Denmark (where the public authority is very decentralized), examining the economic situation of the country twice a year, scored as an extensive network of institutions with a bipartite and tripartite structure.

In Finland, the Economic and Social Council meetings are conducted even monthly and it makes consultations on various economic and social problems. In the same way works the Economic and Social Council of Spain. After 1990 they were created a series of tripartite bodies in the countries of Central and Eastern Europe. Thus, in Poland, issues of economic and social interest are monitored by the Tripartite Commission for Social and Economic Research; in Hungary it was created the Reconciliation of Interests Council (recognized by the Labour Code of 1992); in Russia, the Tripartite Commission for Adjusting Social Affairs and Labour was founded in 1992; in Slovakia, the Council of Economic and Social Agreement is working to this end, etc.

These national bodies as the "Economic and Social Council" play an important role in the legislative activity. For example, in Italy, the National Council for Economy and Labour has the constitutional right to submit draft laws to parliament. In the Netherlands, the government asks the Economic and Social Council's opinion on the draft law with social character, a procedure that is common in Spain, Denmark and Belgium, too.

In Councils of an economic and social nature, the wage issue is also debated: the minimum wage is determined by such agreements and consultations in the Netherlands, Belgium, Greece, Hungary, Poland, Bulgaria etc. In France, collective bargaining issues are debated in the National Commission for Collective Bargaining, which has a particularly important role in preparing draft laws on industrial relations[4].

Over time, it was observed that for the functioning of tripartism, the institution characterized by the existence of three parties - government, employers' representatives and strong enough unions is not sufficient. The positive attitude to consultation and cooperation, the constructive attitude of the parties involved in finding efficient solutions for the economic and social problems that have come to the negotiating table, all these are strictly necessary.

Strengthening democracy and preserving social stability are related in this way by the wisdom of the social partners, according to which overcoming divergent interests of the moment is a long-term common target. Consultations, cooperation and negotiation aim at formulating a policy to promote the common welfare. 
Therefore, there is a triple interaction between the organizations of employers (employers) and workers - social partners and public organizations or entities, i.e. tripartism. This term means transactions, negotiations that take place between the State - represented by the Government - employers and workers, regarding the formulation and implementation of the economic and social policy.

In conclusion, social dialogue encompasses all forms of negotiation and consultation, as well as exchange of information between representatives of the state, employers and employees on topics of common interest of economic and social order.

The concept includes the traditional term of professional relationships, bipartite collective bargaining at the unit or branch of activity, and the relations between social partners and the State. It also includes the tripartite cooperation on labour market issues and it takes place in enlarged tripartite bodies.

That being said, the bipartism and the tripartism are the pillars of the social dialogue. Thus, bipartite relations (between the social partners) are essential for tripartism to be effective. It can be concluded that, after the level at which it is performed; the social dialogue takes place at national, branch and unit level[5].

The dialogue between social partners, in fact trade unions and employer's representatives, is an axiom of a social and economic development of a law state, in our world. In juridical doctrine it was said the social dialogue represents a concrete way to realize the democracy, in economic and social field, because we have to integrate all these in the big frame of the political democracy.

But, in the real economic society, the employees and the employers have a lot of opposite options; all these leading to the collective conflicts which have the source in diametrically opposed positions that they have in work field. That's way it is fundamental to have a balance in collective work relationships, because these balance creates the social pace.

According to the Romanian law, the final end of the social dialogue is the social pace, but we have to go beyond these idea. In fact, the social dialogue and the social pace are not the targets itself. In reality, their existents contribute to the durable economic development of society, to insure decent standard of living for the citizens. For all these reasons it is necessary for the social dialogue to be a permanent component of a social life and, especially, it has to be free of any constraints and not to be influenced by any political changes in the society [6].

\section{REFERENCES}

[1] ] Toyo Faschozin, Coopération tripartite, dialogue social et développement national, in „Revue internationale du travail”, no. 4/2004, p.370.

[2] ]Valer Dorneanu, Gheorghe Bădică, Dreptul muncii, Editura Lumina Lex, Bucureşti, 2002, p.171.

[3] http://www.europarl.europa.eu/

[4] Nistor Valerică, Dreptul muncii - Manual Universitar, Editura Universitară „Danubius”, Galaţi, 2013, p. 98.

[5] Alexandru Athanasiu, Luminiţa Dima, Dreptul muncii, Editura All Beck, Bucureşti, 2005, p. 245.

[6] Ion Traian Ştefănescu, Tratat de Dreptul muncii, vol. 1, Ed. Lumina Lex, 2003, p.117. 